\title{
ADD-CoRE Model Development: Mathematics Teachers Mentoring Based on Pedagogical Content Knowledge and Lesson Study
}

\author{
Ma'rufi $^{1, *}$, Muhammad Ilyas ${ }^{1}$, Salwah $^{1}$, Agustan Syamsuddin $^{2}$ \\ ${ }^{1}$ Mathematics Education Department, Faculty of Teacher Training and Education, Universitas Cokroaminoto Palopo, Indonesia \\ ${ }^{2}$ Magister of Elementary Education, Graduate Program, Universitas Muhammadiyah Makassar, Indonesia
}

Received June 19, 2020; Revised July 30, 2020; Accepted August 25, 2020

\section{Cite This Paper in the following Citation Styles}

(a): [1] Ma'rufi, Muhammad Ilyas, Salwah, Agustan Syamsuddin, "ADD-CoRE Model Development: Mathematics Teachers Mentoring Based on Pedagogical Content Knowledge and Lesson Study," Universal Journal of Educational Research, Vol. 8, No. 10, pp. 4580-4590, 2020. DOI: 10.13189/ujer.2020.081026.

(b): Ma'rufi, Muhammad Ilyas, Salwah, Agustan Syamsuddin (2020). ADD-CoRE Model Development: Mathematics Teachers Mentoring Based on Pedagogical Content Knowledge and Lesson Study. Universal Journal of Educational Research, 8(10), 4580-4590. DOI: 10.13189/ujer.2020.081026.

Copyright $\bigcirc 2020$ by authors, all rights reserved. Authors agree that this article remains permanently open access under the terms of the Creative Commons Attribution License 4.0 International License

\begin{abstract}
This paper presents the process and the results of the development of a mentoring model based on pedagogical content knowledge (PCK) and lesson study, called the ADD-CoRE model, which is valid, practical, and effective. This was Research and Development research. This model was developed through the collaboration between the lecturers at Mathematics Education Study Program and junior high school mathematics teachers in Palopo City. The specific goal of this study was the availability of the ADD-CoRE model syntax, supplemented by supporting tools, namely the model book and the textbook. The ADD-CoRE model development process consisted of four phases, namely the initial assessment, the design, the realization, and the testing, evaluation, and revision phase. The components included in the model were: syntax, social system, the principle of reaction, support system, instructional impact and accompaniment. Field trials were carried out three times at three junior high schools in Palopo City. The results of the development of the teacher mentoring model based on PCK and lesson study (ADD-CoRE models) met the validity criteria, as indicated by the validator assessment results. It also fulfilled the practicality criteria based on the teachers' responses, the model implementation, and the PCK teacher observation results. Besides, it satisfied the effectiveness criteria based on students' responses, students' activities in learning, and students' learning
\end{abstract}

outcomes for the topic of polyhedra. The ADD-CoRE model syntax consisted of six phases, namely: (a) Analyzation, (b) Direction, (c) Demonstration, (d) Collaboration, (e) Rotation, and (f) Evaluation. This research is expected to be a mentoring model for teachers and prospective teachers to improve the quality of learning.

Keywords ADD-CoRE Model, Mentoring, Pedagogical Content Knowledge, Lesson Study

\section{Introduction}

The teacher as a learning agent is a crucial component and one of the determining factors in students' learning processes and outcomes, including in mathematics learning. Having a strong knowledge of the teaching material is very important for a teacher, but it is not adequate for effective teaching [1]. The teacher should know how to teach a specific mathematical concept to students, show particular mathematical ideas, respond to student questions, and design teaching materials, assignments and current curriculum to engage students in a new topic [2]. Pedagogical Content Knowledge (PCK) includes the teacher's knowledge about depictions, analogies, examples, and demonstrations so that students can understand the 
teaching materials. The teachers should know the characteristics of the materials and the students [3]. Such knowledge allows teachers to represent the mathematical concepts to be easily understood by the students [4].

PCK is a distinctive competency of the teachers in the form of content knowledge, the pedagogy, and the knowledge about students. This knowledge is formed over time as the teaching experience increases. PCK is not equal for all teachers, instead it is individual specialized expertise that has different features and it is influenced by the context or teaching atmosphere and experience. PCK can be the same for some teachers and different for other teachers [5]. However, PCK is a meeting point for professional knowledge or teacher expertise. Therefore, many researchers conclude that PCK is the knowledge developed by teachers over time, through experience in teaching the material in various ways to gain the richness of student understanding.

The results of Ma'rufi's research [6] showed that the PCK of mathematics teachers on quadratic function material is diverse in terms of the differences in teaching experiences. The class observation of ten mathematics teachers was conducted in three public schools in Palopo. It was found that in general new teachers were treated equally as experienced teachers. The main tasks of new teachers are teaching, and other tasks related to learning carried out independently without supervising by qualified teachers. This shows that teacher mentoring is vital for fellow teachers and between the lecturers and teachers.

Lesson Study is a learning assessment activity carried out by a group of teachers/lecturers collaboratively and continuously to test and improve the effectiveness of learning. It provides a way for teachers to be able to improve learning systematically. It enables a process for collaborating and designing lessons as well as evaluating the success of the teaching strategies implemented to improve students' learning processes and achievement [7-8].

Teacher professionalism is critical to be developed and fostered continuously through teacher mentoring. PCK is a particular type of knowledge for teachers for effective learning. It is studied and developed through lesson study in collaboration with mathematics education lecturers and mathematics teachers. Thus, the research on the development of mentoring models of mathematics teachers based on PCK through lesson study is paramount to study sustainably.

This research described the development of a mathematics teacher mentoring model based on PCK and lesson study, called ADD-CORE model. This study aimed to determine the process and the development of a valid, practical and effective mathematics teachers mentoring model based on PCK and lesson study (ADD-CoRE models).

\section{Literature Review}

\subsection{Pedagogical Content Knowledge}

PCK is a method to know how to present topics effectively and to encourage students' understanding and learning, while at the same time reducing misconceptions and difficulties about the topic. PCK consists of knowledge about the representation of ideas, analogies, illustrations, examples, explanations, and demonstrations. PCK is a way to represent and formulate the lessons to be understood by students. According to Ma [9], PCK in mathematics learning is teacher's ability to use his/her mathematics knowledge to review and explore mathematical topics and to present the contents in ways that make learning mathematics successful. The teacher should be able to demonstrate the breadth, the depth, and the connectedness of the content knowledge to express mathematical solutions. Furthermore, Stevens [10] explained that PCK emphasizes more on the understanding of mathematics taught and the ability to use mathematics flexibly by discovering various ways to represent ideas for strengthening students' conceptual understanding.

Kilic [2] argued that mathematics learning consists of four components, namely: (1) Knowledge of Subject Matter, (2) Knowledge of Pedagogy (3) Knowledge of Learners and (4) Knowledge of Curriculum. While Magnusson [11] suggested that there are five components of PCK, including; (1) orientation to teaching science, (2) knowledge of assessment, (3) knowledge of curriculum, (4) knowledge of students' understanding, and (5) knowledge of instructional strategies.

Based on the above description about PCK, it can be concluded that PCK in mathematics implies that a teacher must be able to use his/her mathematical knowledge to study mathematical topics taught and use various methods and representations to strengthen students' understanding for students' success in learning mathematics.

\subsection{Lesson Study}

The Lesson Study originates from Japan; it is a systematic process used by Japanese teachers to examine the effectiveness of their teaching to improve learning outcomes. The systematic process is the collaborative work of teachers to develop plans and learning tools; to conduct observations, reflection and revision of the learning plans cyclically and continuously. According to Lewis [7], the ideas in Lesson Study are straight forward; if the teacher wants to improve the learning process, one of the best ways is collaborating with other teachers to design, observe and reflect on the learning process.

There are seven keywords in the definition of lesson study, namely professional development, learning assessment, collaborative, sustainable, collegiality, mutual learning, and learning community. Lesson Study aims to 
foster the teaching profession so that the teachers will enhance their capacity building continually. Professionalism can decrease over time without the mentoring process. The mentoring process is undertaken regularly through collaborative learning. Learning assessment must also be done periodically. For example once or twice a week, because building a learning community means building the culture that facilitates the mutual learning process, respect, assistant and ego restrain as well as peer review.

Based on the explanation above, it can be concluded that lesson study is a learning assessment activity conducted by a group of teachers or lecturers collaboratively and continuously to test and to improve the effectiveness of learning. Through the lesson study, the teachers or lecturers are sharing their understanding and experience along with designing, observing and reflecting on the learning conducted.

\subsection{Teacher Mentoring Model}

Teacher professionalism development, especially for beginner teachers, can be done through teacher induction and mentoring programs. The induction program is one of the stages of sustainable professional development for a teacher. The implementation of a good induction and mentoring program must be systematic and planned based on the concept of collaboration and partnership between teachers employing a professional learning approach. Induction and mentoring programs for new teachers can be carried out by experienced teachers, principals, and school supervisors. In addition, teacher mentoring programs can be developed through cooperation and partnership between the Faculty of Teacher Training and Education and schools. It may also be between lecturers and teachers in reviewing the content of the materials and how to teach then so that students can understand them easily.

Haney in Anwer et al. [12] stated that "mentoring as the relationship between more experienced and less experienced people, as he says' it is actually a relationship between an experienced and a less experienced person in which guidance, advice, support and feedback are provided ". Whereas Collison in Manzar-Abbas et al., [13] believed that "mentoring is the interaction between a novice (the student teacher) and an expert (the teacher), which contributes to the novice's learning".

Mentoring is a model of teacher coaching and assisting through collaboration between lecturers and teachers. Lecturers are required to conduct the Tridharma of higher education, namely: conducting education and teaching, research, and community services. The results of lecturers' research are implemented in the community, including in schools as a form of community services. Teachers are required to undertake self-development, but they need guidance and assistance to develop professionalism sustainably. Collaboration between lecturers and teachers in planning, implementing the learning, and reflecting can improve the quality of learning.

\section{Research Methods}

This research was Research and Development, aiming to develop a model of mathematics teacher mentoring based on PCK and lesson study (ADD-CoRE Model). The model development carried out in this study is based on the development of the Plomp model [14], consisting of five phases, namely: (a) Initial assessment, (b) Design, (c) Realization (construction), and (d) Testing, evaluation and revision, and (e) Implementation. The activities at each phase of the development were as follows.

1) Phase-1 is a preliminary assessment of the development of the ADD-CoRE Model which included an initial investigation of the model and supporting tools.

2) In Phase-2, mathematical teacher mentoring model was designed based on PCK (ADD-CoRE Model) and lesson study. The activities in Phase-2 included (a) designing the syntax, (b) designing the social system (the situation or rules that applied in the ADD-CoRE Model), (c) determining the support system, (e) compiling instructional and following impacts [15]. In this phase, a supporting instrument was also designed following the design of the ADD-CoRE Model. The instruments were designed, namely model books and textbooks.

3) In Phase-3, a PCK-based mathematics teacher mentoring model was created as a continuation of the design phase. The activities in Phase 3 were the realization of the model designed in Phase 2.

4) Activities in Phase 4 focused on two things, validating and conducting field trials. The validation process involved validating Prototype-1 (ADD-CoRE Model) along with the instruments used. The field trial activity aimed to investigate whether the developed model that had been declared valid was effective and efficient. The trials were carried out repeatedly on the expanded samples for each trial. A trial was conducted to obtain results about a PCK-based mathematics teacher mentoring model and a valid, effective and efficient lesson study.

5) Activities in phase-5 were implementing the valid, practical and efficient final prototype of ADD-CoRE model and the supporting instrument for junior high school mathematics teachers in several schools.

The focus of these articles is the four phases of the Plomp development model, an extended trial of several mathematics teachers in Palopo. Validation and trial results were used to examine and describe the valid, practical and efficient ADD-CoRE model. There were three types of instruments used, namely the validity 
model; the effectiveness instruments consisting of student questionnaires, student activity observation sheet, learning outcomes test; and the instruments of practicality comprising teacher questionnaires, observations of the implementation of the ADD-CoRE model, PCK observation sheet.

The ADD-CoRE model and the supporting instruments are said to have fulfilled the effectiveness criteria if (1) students respond positively to the mentoring model especially at the collaboration and rotation stages; (2) students are active in the classroom, and the misconceptions, difficulties, and student errors are reduced; and (3) students' learning outcomes classically exceed the minimum criteria of mastery learnings.

The ADD-CoRE model and supporting instruments are said to have fulfilled the practicality criteria if (1) mentor (expert) and mentee (teacher) provide positive response to the model, that the teacher (mentee) should apply it to create a better learning, and (2) the level of implementation of the ADD-CoRE model falls under the category of most of the aspects implemented. Furthermore, to determine the practicality of the ADD-CoRE model and the learning instruments that refer to the model, the researcher took into account the expert and teacher considerations as well as the observations by two observers using the observation sheet of the ADD-CoRE model.

Afterwards, the data were analyzed quantitatively. Data concerning the results of validation by experts were analyzed to determine the validity of the ADD-CoRE model and its supporting instruments, while the data of the trial in the classroom were used to determine the practicality and effectiveness of the ADD-CoRE model.

The practicality data of the ADD-CoRE model consisted of three parts, namely (1) data concerning the results of the feasibility assessment of the ADD-CoRE model implementation from two experts, (2) data on the general implementation of the ADD-CoRE model from two observers, (3) data of the mentees' (teachers') responses to the ADD-CoRE model, and (4) data about the PCK observation of the mentees (teachers). The following categories were used to analyze whether the data were valid, feasible, and implemented.

The criteria used to decide that the ADD-CoRE model had an adequate degree of validity was modified from Utomo [17], which were if (i) the minimum $\mathrm{V}$ value for all aspects of the supporting instruments was in the "valid" category, and (ii) the minimum $\mathrm{V}$ value for syntax, social systems and the principle of reaction aspects were in the "valid" category. The criterion used to determine that the ADD-CoRE model was feasible was if the minimum $F$ value was in the "quite feasible" category, meaning that the model was "not revised". The criterion used to decide that the ADD-CoRE model had an adequate degree of implementation was if the minimum $\mathrm{W}$ value was in the category of "mostly implemented", meaning that the model was "not revised". If the $\mathrm{W}$ value was in another category, then a revision was necessary to the aspects with low marks. Furthermore, the re-observing and re-analysing would be conducted towards the learning of the revised ADD-CoRE model.

Analysis of the ADD-CoRE model effectiveness was based on three components, namely (1) students' learning outcomes, (2) students' activities, and (3) students' responses to learning. If a student received a learning outcome score $\geq$ the minimum criteria of mastery learning then the student mastered the learning. If the minimum $85 \%$ of students reached the minimum criteria of mastery learning, then classical mastery learning had been achieved. The observation results of students' activities were analysed and described based on four assessment categories, namely: (1) "very unengaged", (2) " unengaged ", (3) " engaged ", (4) "very engaged". It was expected that students' activities were in the engaged category. Students' response of the ADD-CoRE model learning were analysed based on the percentage of positive responses. The minimum effective criterion for students' responses was if more than $50 \%$ of students responded positively to at least $70 \%$ of the aspects asked.

Table 1. Interval for Validity, Feasibility, and Implementation Categories

\begin{tabular}{|c|c|c|c|l|}
\hline No & \multicolumn{3}{|c|}{ Interval } & Category \\
\hline 1 & $\mathrm{~V}<1.5$ & $\mathrm{~F}<1.5$ & $\mathrm{~W}<1.5$ & Invalid, Infeasible, No implementation \\
\hline 2 & $1.5 \leq \mathrm{V}<2.5$ & $1.5 \leq \mathrm{F}<2.5$ & $1.5 \leq \mathrm{W}<2.5$ & Less valid, Less feasible, A little Implementation \\
\hline 3 & $2.5 \leq \mathrm{V}<3.5$ & $2.5 \leq \mathrm{F}<3.5$ & $2.5 \leq \mathrm{W}<3.5$ & Quite valid, Quite feasible, Nearly half Implemented \\
\hline 4 & $3.5 \leq \mathrm{V}<4.5$ & $3.5 \leq \mathrm{F}<4.5$ & $3.5 \leq \mathrm{W}<4.5$ & Valid, Feasible, Mostly Implemented \\
\hline 5 & $4.5 \geq \mathrm{V}$ & $4.5 \geq \mathrm{F}$ & $4.5 \geq \mathrm{W}$ & Very valid, Very feasible, All implemented \\
\hline
\end{tabular}

Source: Darwis [16]

Annotation:

$\mathrm{V}$ is the validity of the ADD-CoRE model

$\mathrm{F}$ is the feasibility of applying the ADD-CoRE model

$\mathrm{W}$ is the implementation of ADD-CoRE model 
The ADD-CoRE model was developed through the collaboration between lecturers at the mathematics education study program at the University of Palopo Cokroaminoto and the junior high school mathematics teachers in Palopo. The subjects of the study were selected from 15 mathematics teachers spreading across 11 junior high schools in Palopo. The ADD-CoRE model was developed on the topic of polyhedra. The topic was chosen based on the discussion involving the subjects of the study. It was found that the topic was not only difficult for students to understand but also for teachers to teach. Then, three mathematics teachers, who had difficulty in teaching, were selected. The three teachers came from Palopo Cokroaminoto Junior High School, Junior High School 8 Palopo, and Junior High School 12 Palopo.

Trials were conducted three times in the three junior high schools in Palopo. Each trial was conducted for four times of mentoring. The first trial was administered for the mathematics teacher at Palopo Cokroaminoto junior high school, the second trial was for the mathematics teacher at junior high school 8 Palopo, and the third trial was for the mathematics teacher at junior high school 12 Palopo.

\section{Result}

\subsection{Results of the ADD-CoRE Model Development}

The developed model was a mentoring model based on PCK and lesson study. The model was abbreviated as an ADD-CoRE Model. PCK is an integrated knowledge between the mathematical content knowledge, pedagogical knowledge and students' knowledge that is implemented in mathematics learning, so the learning materials are easy to understand. There were three components of PCK in this research, namely content knowledge, pedagogical knowledge, and knowledge about students. This research prototype was tested in three junior high schools, namely Palopo Cokroaminoto junior high school, junior high school 8 Palopo, and junior high school 12 Palopo.

The developed PCK and Lesson Study-based mathematics teacher mentoring Model (ADD-CoRE Model) consisted of five components, namely: syntax, social systems, principles of reaction, support systems, and instructional as well as accompaniment impacts. The developed syntax of the ADD-CoRE Model consisted of six phases, namely Analysis, Direction, Demonstration, Collaboration, Rotation, and Evaluation Phase, abbreviated as ADD-CoRE.

Table 2. Syntax of the ADD-CoRE model

\begin{tabular}{|c|c|c|c|}
\hline Phase & Description & PCK Components & Mentor/Mentee Behaviour \\
\hline \multicolumn{4}{|l|}{ Plan } \\
\hline Analysis & $\begin{array}{l}\text { Identifying problems, such as } \\
\text { content and students' } \\
\text { difficulties }\end{array}$ & $\begin{array}{l}\text { Students' knowledge } \\
\text { Content knowledge }\end{array}$ & $\begin{array}{l}\text { The teacher examines and describes the learning } \\
\text { content that is considered the most difficult to teach and } \\
\text { hard for students to understand }\end{array}$ \\
\hline Direction & $\begin{array}{l}\text { Directing/guiding in creating } \\
\text { learning media }\end{array}$ & $\begin{array}{l}\text { Curriculum } \\
\text { Knowledge }\end{array}$ & $\begin{array}{l}\text { The lecturer directs and guides teachers in designing } \\
\text { learning instruments and tools for the class so that they } \\
\text { are easily understood and taught by the teacher }\end{array}$ \\
\hline Demonstration & $\begin{array}{l}\text { Demonstrating/modelling how } \\
\text { to present a certain topic in a } \\
\text { class by the mentor }\end{array}$ & PCK knowledge & $\begin{array}{l}\text { The lecturer demonstrates and models how to teach a } \\
\text { certain topic }\end{array}$ \\
\hline \multicolumn{4}{|l|}{ Do } \\
\hline Collaboration & $\begin{array}{l}\text { Collaborating in managing } \\
\text { learning in mentor and mentee } \\
\text { classes }\end{array}$ & $\begin{array}{l}\text { Pedagogical } \\
\text { knowledge } \\
\text { Content knowledge } \\
\text { Students' knowledge }\end{array}$ & $\begin{array}{l}\text { Lecturers and teachers collaboratively teach a certain } \\
\text { topic in the classroom }\end{array}$ \\
\hline Rotation & $\begin{array}{l}\text { Mentees independently teach a } \\
\text { certain topic to students in the } \\
\text { class }\end{array}$ & $\begin{array}{l}\text { Pedagogical } \\
\text { knowledge } \\
\text { Content knowledge } \\
\text { Students' knowledge } \\
\end{array}$ & $\begin{array}{l}\text { Teachers independently teach a certain topic to students } \\
\text { in the class }\end{array}$ \\
\hline \multicolumn{4}{|l|}{ See } \\
\hline Evaluation & $\begin{array}{l}\text { Evaluating the weakness and } \\
\text { the strengths of the learning to } \\
\text { enhance students' } \\
\text { understanding }\end{array}$ & Students' knowledge & $\begin{array}{l}\text { Mentors and mentees analyse the strengths and } \\
\text { weaknesses of learning conducted to increase students' } \\
\text { understanding }\end{array}$ \\
\hline
\end{tabular}


Table 3. Components of the ADD-CoRE Model

\section{Social systems}

Social systems contain the role of mentor (lecturer), mentees (teachers), and students, as well as the norms or rules that are needed. The social system developed in the mentoring model of mathematics teachers is based on PCK and lesson study (ADD-CoRE Model).

a) The lecturer acts as a mentor, partner, and facilitator. The lecturer as a mentor has the role of directing and guiding in developing learning instruments, as well as demonstrating how to use them. The lecturer acts as a partner or peer teacher in teaching students in the classroom, and as a partner in sharing opinions about students' difficulties. The lecturer as a facilitator has the role of providing analysis to the teacher regarding matters to improve, so the students can understand the content.

b) The teacher plays the role of a mentee, partner, innovator, facilitator, and motivator. The teacher, as a mentee has the role of receiving guidance in developing learning instruments and how to teach them. The teacher acts as a partner or fellow lecturer in teaching students in the classroom. The teacher as a facilitator has the role of educating, teaching, guiding, directing, training, assessing, and evaluating students; providing teaching materials; understanding the difficulties, mistakes and misconceptions of students; as well as facilitating students in achieving the learning goals. Teacher as innovator plays a role in providing meaningful learning experiences to students through the learning innovations used. The teacher, as a motivator has the role of encouraging or motivating students to learn, as well as being a role model for students.

c) Students as contributors have a role in contributing their thoughts to every problem given by the teacher. Students also play an

\begin{tabular}{l|l}
\hline active role in the learning process, both individually and in groups. \\
\hline & The principles of reaction are patterns of activities that describe the lecturer's (mentor)
\end{tabular} reasonable responses to the teacher (mentee). The principle of reaction also relates to the techniques applied by the lecturer in reacting to teacher's activities in the mentoring process, such as asking questions, answering, responding, advising, modelling, training, and so on. Generally, Joice \& Weil [15] stated that the principle of reaction is a guideline for lecturers in respecting and responding stimulus in the form of teacher's behaviour in the mentoring process.

The reaction principle of the developed ADD-CoRE model was designed in such a way to support the achievement of mentoring goals. The principles of this model reaction, namely the lecturer (mentor):

a) giving attention to topics which are considered difficult to teach by the teacher

b) understanding and responding to what the teacher is doing

c) directing and guiding the teacher in designing learning instruments

d) providing opportunities for the teacher to express their opinions

e) providing training in how to teach a difficult topic

f) seeing the teacher as a partner

g) showing the teacher's role in the classroom

h) evaluating teacher's learning in the classroom

i) keeping the mentoring atmosphere conducive

Support System

The support system of the ADD-CoRE model is the things that can support the achievement of mentoring goals. They are facilities, materials, instruments, and tools or media

The ADD-CoRE model needs the following support system:

a) ADD-CoRE model book

b) Textbooks

c) Lesson Plan and Lesson Design

d) Student worksheets

e) Manipulatives

f) Observation sheet of the implementation, activities, and PCK

g) Questionnaire

Instructional impacts and accompaniment impacts are the effects that are directly and Impacts indirectly felt by the teacher or mentee. According to Joice \& Weil [15], the application of a learning model is directed to achieve the optimal learning goals or objectives sustainably.

Instructional Impacts of the mathematics teacher mentoring model based on PCK and lesson study (ADD-CoRE Model) are the content knowledge and pedagogical knowledge as well as the ability to understand the difficulties and misconceptions of students. While the accompaniment impact is that the lecturer and teacher are more confident, competent and creative in their job. Further information is illustrated in Figure 1.

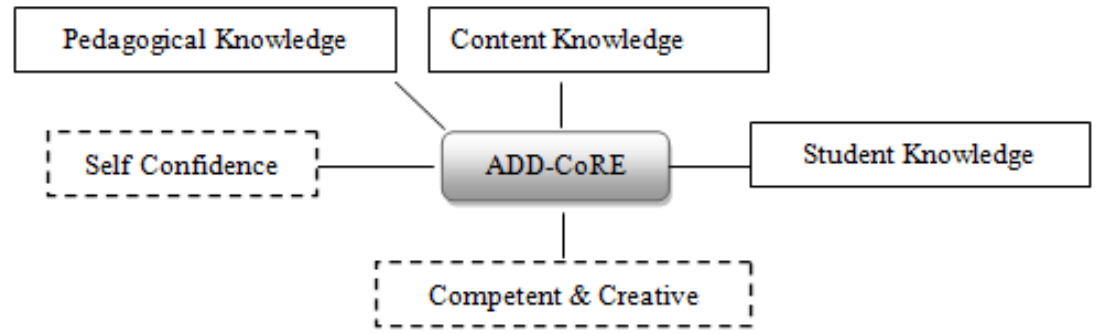

Figure 1. Instructional and Accompaniment Impacts of ADD-CoRE model 


\subsection{Data Analysis of Trial Results}

\subsubsection{Analysis of data validity}

The results of the validation data analysis of the ADD-CoRE model and its supporting instruments are as follows.

Table 4. Results of Validation Data Analysis of the ADD-CoRE Model

\begin{tabular}{|l|c|c|}
\hline \multirow{2}{*}{ Validation Aspects } & \multicolumn{2}{|c|}{ Average Validity Score } \\
\cline { 2 - 3 } & Validator 1 & Validator 2 \\
\hline Syntax & 4.02 & 4.0 \\
\hline Social system & 3.75 & 4.2 \\
\hline Principles of Reaction & 4.02 & 3.92 \\
\hline \multicolumn{2}{|c|}{$\mathbf{3 . 9 8}$} \\
\hline \multicolumn{2}{|c|}{ V The ADD-CoRE model is categorised as Valid } \\
\hline
\end{tabular}

Based on Table 4, it can be stated that the syntax, social system, and principles of the reaction of the ADD-CoRE model were valid. The development of the ADD-CoRE model in the form of syntax, social systems, and the principles of reaction had been through several assessments until it was stated as valid by the validators. The validity results of the ADD-CoRE model in Table 3 are the final validation sheets assessed by two validators.

Table 5. Results of Validation Data Analysis of Supporting Instruments

\begin{tabular}{|l|c|c|}
\hline \multirow{2}{*}{ Validation Aspects } & \multicolumn{2}{|c|}{ Average Validity Score } \\
\cline { 2 - 3 } & Validator 1 & Validator 2 \\
\hline Teaching Material & 3.4 & 4.0 \\
\hline Model Books & 4.0 & 4.2 \\
\hline Student Worksheets Sheet on the \\
\hline $\begin{array}{l}\text { Observation the } \\
\text { Implementation of } \\
\text { Mentoring Model }\end{array}$ & 3.5 & 3.8 \\
\hline Student Questionnaire & 3.8 & 3.6 \\
\hline $\begin{array}{l}\text { Students' Activity Observation } \\
\text { Sheet }\end{array}$ & 4.0 & 3.7 \\
\hline \multicolumn{2}{|c|}{3.8} \\
\hline \multicolumn{2}{|c|}{ The ADD-CoRE Model Supporting instruments are } \\
categorised as Valid \\
\hline
\end{tabular}

Table 5 above revealed that the results of the validity analysis of the ADD-CoRE model supporting instruments, such as textbooks, model books, student worksheets, observation sheets of the ADD-CoRE model implementation, students' questionnaire, students' activity observation sheet were classified into the valid category. All aspects for the supporting instruments were in the valid category. Therefore, the supporting media of the ADD-CoRE model was declared to be suitable for use in the trial.

\subsubsection{Data Analysis of the ADD-CoRE Model Implementation}

Data Analysis of the ADD-CoRE Model Implementation is as follows.

The results of the implementation analysis of the ADD-CoRE model showed that some aspects of the mentoring process were carried out well. Thus, the ADD-CoRE model was practical or feasible to use in mentoring processes, and could be recommended to use by other mentees.

\subsubsection{Data Analysis of Teacher Response (Mentee) of the ADD-CoRE Model}

Based on the analysis of teacher responses, it was found that the teacher was very satisfied with each step of the ADD-CoRE model and the application of ADD-CoRE model-based learning in the classroom. The teachers believe that the ADD-CoRE model can be applied to the teachers in other schools. The ADD-CoRE mentoring model provides enormous benefits for improving learning in the classroom, especially to improve the teacher's PCK skills. The teacher responses results also illustrated that the ADD-CoRE model can increase teacher confidence because the learning was very well planned so that the teacher was ready to be in the classroom. Therefore, based on the results of the analysis of teacher responses, it was found that the ADD-CoRE model was practical to be used in the mentoring process, and was very appropriate to be used in learning.

Table 6. Results of the ADD-CoRE Model Implementation Data Analysis

\begin{tabular}{|c|c|c|c|c|c|}
\hline \multirow[b]{2}{*}{ Aspects } & \multicolumn{3}{|c|}{ The average level of implementation in meeting 1 to } & \multirow{2}{*}{$\begin{array}{c}\text { Average } \\
\text { Total }\end{array}$} & \multirow[b]{2}{*}{ Category } \\
\hline & $\begin{array}{c}\text { Cokroaminoto } \\
\text { Junior High } \\
\text { School } \\
\end{array}$ & $\begin{array}{l}\text { Junior High } \\
\text { School } 8 \text { Palopo }\end{array}$ & $\begin{array}{c}\text { Junior High } \\
\text { School } 12 \\
\text { Palopo } \\
\end{array}$ & & \\
\hline Syntax & 2.6 & 3 & 4.4 & 3.3 & $\begin{array}{l}\text { Half of the Aspects were } \\
\text { Implemented }\end{array}$ \\
\hline Social system & 2.8 & 3.2 & 4.7 & 3.6 & Most aspects were implemented \\
\hline Principles of Reaction & 2.7 & 3.7 & 4.8 & 3.7 & Most aspects are implemented \\
\hline $\begin{array}{c}\text { Total Level of } \\
\text { Implementation }\end{array}$ & 2.7 & 3.3 & 4.6 & 3.53 & $\begin{array}{l}\text { Aspects were Partially } \\
\text { Implemented }\end{array}$ \\
\hline
\end{tabular}




\subsubsection{Analysis of the Students' Response Data to the Teachers' Learning}

The analysis results of the students' responses to the ADD-CoRE model learning-based in the collaboration and rotation stages of the first field trial in SMP Cokroaminoto Palopo indicated that $58 \%$ of students had positive responses. The second field trial conducted in SMP Negeri 8 Palopo showed that $73 \%$ students gave positive responses and the third field trial in SMP Negeri 12 Palopo revealed that $82 \%$ students responded the ADD-CoRE-based learning model positively. Based on the findings, the average of the positive responses to the ADD-CoRE-based learning model in the collaboration and rotation stages was $71 \%$. The result of the students' responses data indicated that the ADD-CoRE-based learning model was effective to be implemented in learning.

\subsubsection{Analysis of Students Activities Data}

The analysis of students' activities data in learning were described as follow.

Table 7. The Analysis Result of Students Activities Data

\begin{tabular}{|c|c|c|c|c|c|c|}
\hline \multirow{2}{*}{$\begin{array}{c}\text { Field } \\
\text { Trial }\end{array}$} & \multicolumn{4}{|c|}{$\begin{array}{c}\text { Mean percentage of Students } \\
\text { Activities (\%) }\end{array}$} & \multirow{2}{*}{$\begin{array}{c}\text { Mean } \\
\text { Total } \\
\text { Meeting }\end{array}$} & \multirow{2}{*}{ Category } \\
\cline { 2 - 5 } & 1 & 2 & 3 & 4 & & \\
\hline I & 50.8 & 52 & 52.3 & 53 & $\mathbf{5 2}$ & $\begin{array}{c}\text { Not } \\
\text { engaged }\end{array}$ \\
\hline II & 67 & 69 & 72 & 72 & $\mathbf{7 0}$ & Engaged \\
\hline III & 85 & 85 & 90 & 92 & $\mathbf{8 8}$ & $\begin{array}{c}\text { Very } \\
\text { Engaged }\end{array}$ \\
\hline Mean & 67.6 & 68.7 & 71.4 & 72.3 & $\mathbf{7 0}$ & Engaged \\
\hline
\end{tabular}

The analysis results of students' activities data indicated that the students' activities were categorized as engaged (active). The findings showed that the ADD-CoRE-based learning model was effective to be applied in learning.

\subsubsection{Data analysis of Students' Mathematics Test Result}

Figure 2 described the mean of the students' results in three schools (three field trials).

Figure 2 showed that the students' activities in the first field trial (SMP Cokroaminoto Palopo) did not achieve the minimum criteria of mastery learning criteria. It was seen from the mean of post-test (62.24), which was below the minimum criteria of mastery learning criteria (65). However, the students learning outcomes in the schools showed an improvement.

The data presented in Figure 2 were obtained from the students' learning outcomes carried out in four lessons for each field trial. The first field trial showed an unsatisfactory result; however, it was improved in the second and third field trial. The third trial conducted in SMPN 12 Palopo indicated that the learning outcome of over $85 \%$ of students was higher than 65 (the minimum mastery learning criteria). Thus, the ADD-CoRE-based learning model was effective to be implemented in learning.

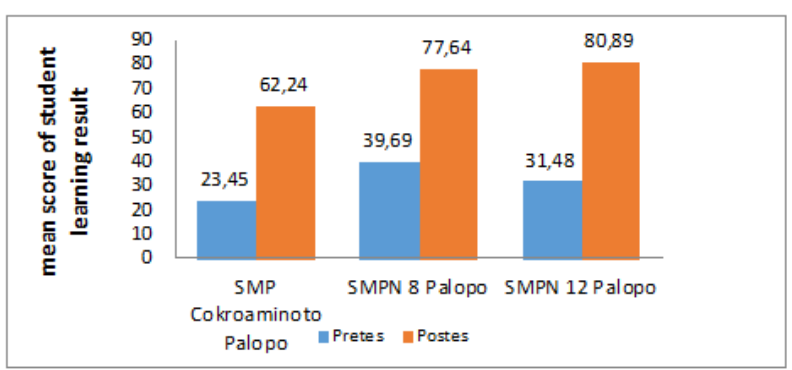

Figure 2. Mean score of the students' learning outcomes

\subsection{Research Findings Discussion}

\subsubsection{Research Findings Observation of Pedagogical Content Knowledge}

a. Knowledge of subject matter

The definition accuracy was found in the first field trial in SMP Cokroaminoto Palopo.

Teacher : Which are the cube sides?

Student : The sides are the edges, Miss.

Teacher : It is incorrect; the cube sides are the planes.

Do you know the volume of a cube?

Student : Side x side x side, Miss.

Teacher : Yes. It's correct.

Based on the teacher and student' discussion, the teacher commented that the student answer was wrong when $\mathrm{s} / \mathrm{he}$ said the side was the length of the cube edge. However, the teacher stated that it was correct when the students mentioned that the formula of the cube volume was the side to the power of 3 . The teacher should emphasize to the student that the length of the cube edge was equal to the length of the side to avoid misconception. Therefore, the cube volume was the side length to the power of 3 . The concepts, formula, and procedures used by the teacher in mathematics learning process were correct and accurate.

In the second field trial in SMPN 8 Palopo, the teacher started the class by showing the learning manipulative of a cube. The teacher explained the accuracy definition by mentioning that the cube length or a unit cube in the cube length was three, the width or a unit cube in width was three, and the height was three. The teacher should direct the student to think that the length, width, and height of the cube had the same length, namely three-unit cubes. L, $\mathrm{W}$ and $\mathrm{H}$ were named as the side. Thus, the cube volume was length $\mathrm{x}$ width $\mathrm{x}$ height equal to side $\mathrm{x}$ side $\mathrm{x}$ side. However, the concept, formula and procedures applied were correct and accurate.

In the third field trial at SMPN 12 Palopo; the facts, definition and mathematics symbols related to the material were explained accurately. Also, the simple language was 
used to help the students understand the materials easily. The related concepts, formula and procedures were correct. These were based on the students' answers about the cube volume, namely $\mathrm{L} \times \mathrm{W} \times \mathrm{H}$, the teacher emphasized that $\mathrm{LWH}=\mathrm{LHW}$.

Based on the description of the subject matter knowledge, the three teachers explained the materials properly because they had applied the analyzing stages of ADD-CoRE-based learning model. In the stages, the teacher and lecturers identify the material difficulties to avoid inaccuracy definition, concept, and procedures. As Kell \& Forsberg's research findings [18] reported that the participant needs someone to talk about his/her learning when $\mathrm{s} /$ he needs it. The mentor became not only a friend to share stories but also a professional person who guide, help, encourage and consider about the learning materials.

\section{b. Knowledge of pedagogy}

In the first field trial, the learning steps conducted by the teacher were coherent, interesting, and scientific (observing, asking, trying, reasoning and presenting) by scaffolding. The materials were not explained directly; however, the teacher gave feedback to the students. The questions were made to attract the students' attention, and the given problems were clear, appropriate and related to real life.

In the second and third field trial, the similar learning steps were undertaken, namely the concept of the cube and cuboid area presented through visual media. The video showed examples of three-dimensional geometry around the students. The teacher also presented a learning video consisting of ways to determine the cuboid volume using a unit cube. In addition, the teacher gave the same learning manipulatives as seen on the video to allow students determining the volume of polyhedron. The student worksheets were as a means for students to discover the formula of the volume and surface area of three-dimensional geometry. The teacher only provided limited assisted to the students, particularly in the difficult parts, using scaffolding technique. The teacher employed guided inquiry method and peer tutor in the learning process to make the students understand the learning material easily. According to Ma'rufi [19-20], teachers played essential roles in developing the students' knowledge and mathematical skills. The improvement of teachers' pedagogy knowledge was one of the solutions to conduct the roles. One of the ways that can be done by teachers in order to improve pedagogy is to transform their pedagogy with reflective action or reflective thinking toward their instructional practices so that they can construct their professional development as a professional teacher [21-22].

\section{c. Knowledge of student}

Students experienced difficulty when answering the question of "how many unit cubes to fill the cuboid?".
Students had difficulty and did not recall that the solution was by multiplying the length, width, and height. The source of students' difficulty was when linking the number of unit cubes in one cuboid or cube to the multiplication of the length, width, and height. When this difficulty occurred, the teacher told students to try by themselves using the manipulatives provided. The teacher asked students to try whether the length $=3 \mathrm{~cm}$, the width $=3 \mathrm{~cm}$, and the height $=3 \mathrm{~cm}$, then the number of cube units in the three-dimensional geometry was 27 . The number of 27 was the product of length, width, and height of the cube or cuboid. According to Ma'rufi [23], effective teachers are those who can master the learning materials and how to convey it to students; thus, students can understand the material without misconceptions.

Students' difficulty was also found in the operation of algebra and integers. Many students found that algebraic operations were challenging. The teacher overcame this issue by the peers in each group. Peers would explain the method to their friends with difficulties. Thus, students can be sure of the answers they get by discussing with peers related to algebraic operations used in the problem solving process carried out. Therefore, students will be more confident of the solutions obtained [24].

\subsubsection{The Validity, Practicality and Effectiveness of the ADD-CoRE Model}

The analysis results of validity and trial data showed that the ADD-CoRE model met all indicators of validity, practicality, and effectiveness. The validation results of the two assessments showed that both validators established that the syntax, social system, the principle of reaction, and supporting instruments such as textbooks, model books, worksheets, observation sheets and questionnaires were valid.

The results of the practicality analysis indicated the teacher's response to the ADD-CoRE model was excellent. The teacher provided positive responses to the ADD-CoRE model and recommended to other teachers because each step of the ADD-CoRE model was meaningful for the mentees. The teacher thought they were closer to the mentors and were guided and directed well in designing the learning. This case is in line wih Anwer's opinion [12], who argued that a mentor is more than a teacher. $\mathrm{S} / \mathrm{he}$ facilitates someone by knowledge sharing, guidance; direction based on her/his experiences over the years. The key indicator for effective mentoring is "a good relationship between mentor-mentee".

The results of the practicality analysis also showed that some aspects of the mentoring process were well implemented. So, the ADD-CoRE model was classified as practical or appropriate to use in the mentoring process, and can be recommended for other mentees. Furthermore, these results indicated that the interaction between mentor and mentee run well. Mentoring cannot be adequately implemented if the interaction between mentor and mentee 
is not well established. Both should be cooperative and share mutual trust. This finding agrees with Pitton in Richards [25], who argued that the interaction between mentor and mentee must be based on trust. Trust and open communication are the virtue of mentoring.

The data concerning the effectiveness analysis reported that the ADD-CoRE model was effective to use in the learning process. This conclusion was based on the analysis of student responses, student activities, and student learning outcomes tests. Students responded positively to the ADD-CoRE-based learning model. Besides, students were also engaged in the activities after the trial employing ADD-CoRE-based learning model. In the final trial conducted at SMPN 12 Palopo, more than $85 \%$ of the students score above 65 (the minimum criteria of mastery learning).

\section{Conclusions}

The ADD-CoRE model was developed by the collaboration between the lecturers of mathematics education study program and junior high school mathematics teachers in Palopo. The results of the development of the teacher mentoring model based on PCK and lesson study (ADD-CoRE models) satisfied the criteria of validity, effectiveness, and practicality. The results are presented as follows.

The ADD-CoRE model met the validity criteria based on the assessment results of the validators. It also satisfied the practicality criteria based on the teacher's responses, the model feasibility, and the observation results of the teacher's PCK. In addition, it fulfilled the effectiveness criteria following the student responses, student activities in learning, and students' learning outcomes on the material of polyhedron.

The ADD-CoRE Model syntax consisted of six phases, namely (a) Analysis, (b) Direction, (c) Demonstration, (d) Collaboration, (e) Rotation, and (f) Evaluation.

\section{Acknowledgments}

The research team would like to thank the Directorate of Research and Community Service at the Ministry of Research, Technology and Higher Education for financing this multi-year research through excellent primary research grant of higher education. We also would like to extend our gratitude to the junior high school mathematics teachers and lecturers who have been involved in data collection.

\section{REFERENCES}

[1] Ball, D. L., \& Bass, H. Interweaving content and pedagogy in teaching and learning to teach: knowing and using mathematics. In J. Boaler (Ed.), Multiple perspectives on mathematics teaching and learning. Westport, UK: Ablex. 83-104, 2000.

[2] Kilic, H. Preservice secondary mathematics teachers' knowledge of students. Turkish Online Journal of Qualitative Inquiry, Vol. 2, No. 2, 2011.

[3] Syamsuddin, A., Juniati, D., \& Siswono, T. Y. E., Understanding the Problem Solving Strategy Based on Cognitive Style as a Tool to Investigate Reflective Thinking Process of Prospective Teacher. Universal Journal of Educational Research, Vol. 8, No. 6, 2614-2620, 2020.

[4] Syamsuddin, A. Describing taxonomy of reflective thinking for field dependent-prospective mathematics teacher in solving mathematics problem. International Journal of Scientific \& Technology Research, Vol. 9, No. 3, 4418-4421, 2020.

[5] Hawkins, W. J. An investigation of primary teachers' pedagogical content knowledge when teaching measurement to years three and four. In 12th International Congress on Mathematical Education. ICME, Korea National Univeristy of Education, 1874-1883, 2012.

[6] Ma'rufi. Podagogical content knowledge (PCK): special knowledge type of teaching effective learning (case study of high school). International Journal of Library Science Vol. 14 , Issue 2, 2016

[7] Lewis, C. Lesson study: A handbook of teacher-led instructional change. Philadelphia: Research for Better Schools, 2002.

[8] Lewis, C., Perry, R., Hurd, J., \& O'Connell, M. P. Lesson study comes of age in North America. Phi delta kappan, Vol. 88, No. 4, 273-281, 2006.

[9] Ma, L. Knowing and teaching elementary mathematics: teachers' understanding of fundamental mathematics in China and the United States. New York: Routledge, 1999.

[10] Stevens, B. B. A. The development of pedagogical content knowledge of a mathematics teaching intern: The role of collaboration, curriculum, and classroom context. Doctoral dissertation, University of Missouri--Columbia, 2005.

[11] Magnusson, S., Krajcik, J., \& Borko, H. Nature, sources, and development of pedagogical content knowledge for science teaching. In J. Gess-Newsome \& N. G. Lederman (Eds.), Examining pedagogical content knowledge. Washington, DC: National Academy Press, 95-132, 1999.

[12] Anwer, M., Hong, S. H. E. N., Alwi, S., \& Raza, D. Factors of effective mentoring: an empirical study of post-graduate faculty and students in pakistan. New Horizons, Vol. 11, No. 1, 41-58, 2017.

[13] Manzar-Abbass, S. S., Ahmed, S., \& Malik, N. A. Primary school teachers'perceptions about mentors'role in their professional development. New Horizons, Vol. 11, No. 2, 47-109, 2017

[14] Plomp, Tjeerd. Educational and training system design. Enschede, The Netherlands: Univercity of Twente, 1997.

[15] Joyce, B. \& Weil, M. Models of teaching. Boston: Allyn and Bacon, 1992.

[16] Darwis. Model pembelajaran matematika dengan 
mempertimbangkan kecerdasan emosional (Mathematical learning model by considering emotional intelligence). Doctoral dissertation, Universitas Negeri Surabaya, 2006.

[17] Utomo, D. P. Pengembangan model pembelajaran kooperatif matematika yang beorientasi pada kepribadian siswa (model pkbk) di sekolah dasar (development of mathematical cooperative learning models oriented to student personality (pkbk model) in elementary schools. Jurnal Pendidikan dan Pembelajaran, Vol. 18, No. 2, 145-152, 2011.

[18] Kell, S., \& Forsberg, N. The role of mentoring in physical education teacher education: Mentoring in practice. Physical \& Health Education Journal, Vol. 81, No. 3, 1-14, 2016.

[19] Ma'rufi, Ilyas, M., \& Salwah. Junior high school mathematics teachers' pedagogical content knowledge in teaching of polyhedra. Journal of Physics: Conference Series, IOP Publishing, Vol. 1088, No. 1, 012052, 2018.

[20] Ma'rufi. Teacher's pedagogical content knowledge on students-matter on quadratic function materials. Proceedings $3^{\text {rd }}$ ICRIEMS "The Global Challenges on the Development and the Education of Mathematics and Science. Yogyakarta (Indonesia): Faculty of Mathematics and Science, 2016.
[21] Naidoo, J., Singh-Pillay, A., Exploring Mathematics Teachers' Professional Development: Embracing the Fourth Industrial Revolution. Universal Journal of Educational Research, Vol. 8, No. 6, 2501 - 2508, 2020.

[22] Agustan, S., Juniati, D., \& Siswono, T. Y. E. Profile of male-field dependent (FD) prospective teacher's reflective thinking in solving contextual mathematical problem. American Institute of Physics Conference Series, Vol. 1867, No. 2, 020034, 2017.

[23] Ma'rufi, Budayasa, I. K., \& Juniati, D. Pedagogical content knowledge: teacher's knowledge of students in learning mathematics on limit of function subject. Journal of Physics: Conference Series, IOP Publishing, Vol. 954, No. 1, 012002 , 2018.

[24] Agustan, S., Juniati, D., \& Siswono, T. Y. E., Reflective thinking in solving an algebra problem: a case study of field independent-prospective teacher. Journal of Physics: Conference Series, Vol. 893, No. 1, 012002, 2017.

[25] Richards, J. C. Mentoring preservice teachers in a community of practice summer literacy camp: master's students' challenges, achievements, and professional development. Qualitative Report, Vol. 15, No. 2, 318-339, 2010 . 